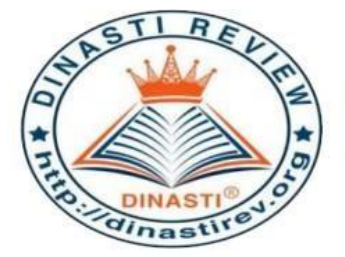

+62 878-9658-6407

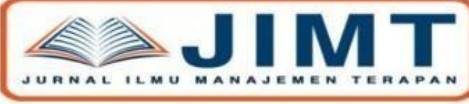

087896586407

https://dinastirev.org/JIMT editor@dinastirev.org

\title{
PENGARUH BAURAN PEMASARAN TERHADAP KEPUTUSAN PEMBELIAN PADA USAHA MIKRO KECIL DAN MENENGAH (UMKM) SALE PISANG PURWOBAKTI MUARO BUNGO
}

\author{
Yeki Candra ${ }^{1}$, Desi Permata Sari $^{2}$, Weweni Ismail ${ }^{3}$ \\ ${ }^{1)}$ Universitas Putra Indonesia YPTK, Padang \\ ${ }^{2)}$ Universitas Putra Indonesia YPTK, Padang \\ ${ }^{3)}$ Universitas Putra Indonesia YPTK, Padang
}

ARTICLE INFORMATION

Received: 23 November 2019

Revised: 25 November 2019

Issued: 29 November 2019

Corresponding author: first author E-mail:

yekicandra19@gmail.com desipermatasari735@gmail.com wenyismail@gmail.com

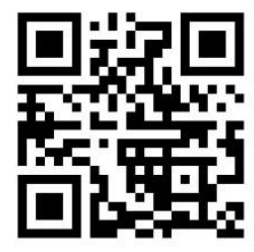

DOI:10.31933/JIMT
Abstrak: Penelitian ini bertujuan untuk mengetahui seberapa besar pengaruh bauran pemasaran terhadap keputusan pembelian. Metode analisis yang digunakan adalah analisis regresi berganda. Metode pengumpulan data dalam penelitian ini adalah dengan menggunakan kuesioner yang diisi oleh responden adalah konsumen Pisang Purwobakti Sale Muaro Bungo. Hasil penelitian ini adalah pengaruh positif dan signifikan antara produk terhadap keputusan pembelian pada Penjualan Pisang Pisang Purwobakti. Tidak ada pengaruh positif dan signifikan antara harga dan keputusan pembelian pada Penjualan Pisang Pisang Purwobakti. Tidak ada pengaruh positif dan signifikan antara distribusi keputusan pembelian terhadap Penjualan Pisang Purwobakti Muaro Bungo. Ada pengaruh positif dan signifikan antara promosi terhadap keputusan pembelian pada Penjualan Pisang Purwobakti Muaro Bungo. Secara simultan (bersamasama) produk, harga, distribusi, promosi berpengaruh signifikan terhadap keputusan pembelian pada Penjualan Pisang Purwobakti Muaro Bungo. Akhirnya penulis menyarankan bahwa Penjualan Pisang Muaro Bungo Purwobakti dapat meningkatkan produk dengan memperhatikan kualitas produk dan promosi, karena kualitas produk dan promosi adalah hal-hal yang mampu membuat keputusan pembelian.

Kata Kunci: Keputusan Pembelian, bauran pemasaran, Produk, Harga, Distribusi, Promosi 


\section{PENDAHULUAN}

Usaha mikro kecil dan menengah (UMKM) sebagai salah satu sektor unggulan, bahkan jadi penopang utama perekonomian Indonesia. Mempunyai peran penting dan strategis dalam pembangunan ekonomi khususnya dikota Muaro Bungo. Selain berperan dalam pertumbuhan ekonomi dan penyerapan tenaga kerja, UMKM juga berperan dalam mendistribusikan hasil pembangunan.

Menurut Rudjito (2013) Usaha Mikro Kecil dan Menengah (UMKM) adalah usaha yang punya perananan dalam perekonomian negara Indonesia, baik dari sisi lapangan kerja yang tercipta maupun dari sisi jumlah usahanya. UMKM di indonesia selama ini telah memberikan kontribusi pada Produk Domestik Bruto (PBD) sebesar 57-60\% dan tingkat penyerapan tenaga kerja sekitar 97\% dari seluruh tenaga kerja nasional (Profil Bisnis UMKM oleh LPPI dan BI tahun 2015). Maka diperkirakan dari 2014-2016 jumlah UMKM lebih dari 57.900.000 unit dan pada tahun 2017 jumlah UMKM diperkirakan berkembang sampai lebih dari 59.000.000 unit. UMKM cukup membuktikan sebagai salah satu serana untuk membangun perekonomian dan kesejahteraan masyarakat.

Data dari Kementerian Koperasi dan Usaha Kecil Menengah). Sektor pertanian mempunyai peran penting di kabupaten Muaro Bungo Propinsi Jambi terdapat berbagai komoditi subsektor pertanian pangan, palawija dan kultikultura, salah satu nya adalah pisang. Komoditi ini berpotensi untuk diolah untuk meningkatkan nilai tambah sekaligus untuk mencegah kemiskinan, Kemudian diolah menjadi sale pisang. Sale Pisang merupakan salah satu bentuk UMKM yang berguna untuk meningkatkan perekonomian masyarakat khusus nya di Purwobakti Muaro Bungo. Sesuai dengan fungsi UMKM yang memajukan perekonomian daerah dimana Sale Pisang itu sendiri bergerak disektor makanan yang merupakan oleh-oleh dan ciri khas kota Muaro Bungo. Oleh karana itu, tidak heran apabila pendapatan UMKM menjadi sumber pendapatan terbesar dalam pembangunan ekonomi daerah. Sebagai pembagunan ekonomi daerah UMKM senantiasa mengandung resiko yang relatif besar. Sale Pisang salah satu UMKM yang menawarkan produk pisang dalam kamasan dengan kelembutan dan rasa yang nikmat serta berbagai inovasi pisang lain nya.

Identifikasi Masalah Dari latar belakang masalah diatas yang telah diuraikan dalam kajian teori, banyak faktor yang mempengaruhi keputusan pembelian yaitu : 1) Faktor budaya (budaya, sub budaya, dan kelas sosial) masih rendah, 2) Faktor sosial (kelompok referensi, keluarga, peran dan status) masih rendah, 3) Faktor pribadi (usia dan siklus hidup keluarga, pekerjaan dan lingkungan ekonomi, kepribadian, dan gaya hidup) masih rendah, 4) Faktor psikologis (motivasi, persepsi,pembelajaran dan motivsi) terhadap masih rendah, 5) Faktor lingkungan (ekonomi teknologi, politik, dan budaya) kurang optimal, 6) Faktor marketing mix ( produk, harga, distribusi dan promosi) belum terlaksana secara baik.

\section{Rumusan Masalah}

1) Berdasarkan batasan masalah penelitian yang telah disampaikan sebelumnya, maka dirumuskan permasalahannya sebagai berikut:

2) Bagaimana pengaruh Produk secara parsial terhadap keputusan pembelian pada UMKM Sale Pisang Purwobakti Muaro Bungo?

3) Bagaimana pengaruh Harga secara parsial terhadap keputusan pembelian pada UMKM Sale Pisang Purwobakti Muaro Bungo?

4) Bagaimana pengaruh Distribusi secara parsial terhadap keputusan pembelian pada UMKM Sale Pisang Purwobakti Muaro Bungo? 
5) Bagaimana pengaruh Promosi secara parsial terhadap keputusan pembelian pada UMKM Sale Pisang Purwobakti Muaro Bungo?

6) Bagaimana pengaruh Produk, Harga, distribusi, dan Promosi secara bersama-sama terhadap keputusan pembelian pada UMKM Sale Pisang Purwobakti Muaro Bungo?

\section{Tujuan Penelitian}

1) Untuk mendeskripsikan Pengaruh Produk terhadap keputusan pembelian pada UMKM Sale Pisang Purwobakti Muaro Bungo.

2) Untuk mendeskripsikan Pengaruh Harga terhadap keputusan pembelian pada UMKM Sale Pisang Purwobakti Muaro Bungo.

3) Untuk mendeskripsikan Pengaruh Distribusi secara parsial terhadap keputusan pembelian pada UMKM Sale Pisang Purwobakti Muaro Bungo.

4) Untuk mendeskripsikan Pengaruh Promosi secara parsial terhadap keputusan pembelian pada UMKM Sale Pisang Purwobakti Muaro Bungo.

5) Untuk mendeskripsikan Pengaruh Produk, Harga, distribusi, dan Promosi secara bersamasama terhadap keputusan pembelian pada UMKM Sale Pisang Purwobakti Muaro Bungo.

\section{KAJIAN PUSTAKA}

Penelitian yang dilakukan oleh Soraya (2011) berjudul "Pengaruh Bauran Pemasaran Jasa terhadap Keputusan Pembelian Konsumen pada Gardenia Cafe Medan Tempat/Distribusi, berpengaruh positif dan signifikan terhadap Keputusan Pembelian Konsumen pada Gardenia Cafe Medan. Dan penelitian Tri Yulianti (2013), dengan judul "Pengaruh Promotional Mix Terhadap Keputusan Pembelian Sepeda Motor Yamaha Pada Masyarakat Kecamatan Jebres Surakarta.

\section{Definisi Pemasaran}

Pemasaran merupakan aktivitas yang sangat penting bagi perusahaan untuk mencapai tujuannya. Sekarang sudah banyak pesaing yang memiliki produk yang sejenis, perusahaan harus bisa menentukan strategi yang tepat agar perusahaan bisa terus berkembang seiring dengan perkembangan zaman. Perusahaan harus melakukan inovasi produk agar produk yang dijual sesuai dengan kebutuhan para konsumen dan dapat memuaskan mereka.

Menurut Kotler dan Armstrong (2014) Pemasaran adalah proses dimana perusahaan menciptakan nilai bagi pelanggan dan membangun hubungan yang kuat dengan pelanggan, dengan tujuan menangkap nilai dari pelanggan sebagai imbalannya.

\section{Manajemen Pemasaran}

Manajemen pemasaran mengatur semua keinginan pemasaran, karena itu manajemen pemasaran sangat penting bagi perusahaan. Menurut Kotler dan Keller (2013) Manajemen pemasaran adalah suatu gabungan antara seni dengan ilmu mengenai pemilihan target pasar dan membangun hubungan yang menguntungkan dengan mereka. Menurut Tjiptono (2011) Manajemen pemasaran merupakan sistem total aktivitas bisnis yang dirancang untuk merencanakan, menetapkan harga, dan mendistribusikan produk. Jasa dan gagasan yang mampu memuaskan keinginan pasar dalam rangka mencapai tujuan organisasional.

\section{Bauran Pemasaran (Marketing Mix)}

Marketing Mix atau bauran pemasaran merupakan peranan penting dalam pemasaran yang dapat menghubungani konsumen untuk membeli produk atau jasa yang ditawarkan. Marketing mix juga menentukan keberhasilan perusahaan dalam mengejar profit. Menurut 
Kotler dan Amstrong (2014) marketing mix adalah alat pemasaran yang baik yakni seperangkat produk, harga, promosi, distribusi, dikombinasikan untuk menghasilkan respon yang diinginkan pasar sasaran. Menurut Rambat Lupiyoadi (2013), bauran pemasaran merupakan perangkat/alat bagi pemasar yang terdiri atas berbagai unsur suatu program pemasaran yang perlu dipertimbangkan agar implementasi strategi pemasaran dan penentuan posisi yang ditetapkan dapat berjalan sukses.

Defenisi diatas dapat disimpulkan bahwa bauran pemasaran adalah suatu alat atau perangkat yang akan menentukan tingkat keberhasilan pemasaran bagi perusahaan, dan semua ini ditunjukan untuk memberikan kepuasan, bauran pemasaran diklasifikasikan menjadi $4 \mathrm{P}$.

\section{Produk}

Produk merupakan elemen penting dalam sebuah program pemasaran strategi produk dapat mempengaruhi strategi pemasaran lainnya. Pembelian sebuah produk bukan hanya sekedar untuk memiliki produk tersebut tetapi juga untuk memenuhi kebutuhan dan keinginan konsumen. Secara konseptual, produk adalah pemahaman subyektif dari produsen atas sesuatu yang ditawarkan sebagai usaha untuk mencapai tujuan organisasi melalui pemenuhan kebutuhan dan keinginan konsumen, sesuai dengan kompetensi dan kapasitas organisasi serta daya beli pasar. Menurut Tjiptono (2013) produk adalah segala sesuatu yang ditawarkan produsen untuk diperhatikan, diminta, dicari, dibeli, digunakan, atau dikonsumsi pasar sebagai pemenuhan kebutuhan atau keinginan pasar yang bersangkutan.

Menurut Kotler dan Armstrong (2015), produk adalah semua hal yang dapat ditawarkan pada pasar untuk menarik perhatian, akuisisi, penggunaan atau konsumsi yang dapat memuaskan sesuatu keinginan atau kebutuhan.

Berdasarkan pendapat para ahli diatas dapat disimpulkan bahwa produk dalam penelitian ini adalah sesuatu yang dapat ditawarkan produsen untuk dipehatikan, diminati, dicari, dibeli, digunakan untuk dikonsumsi dalam memenuhi kebutuhan dan keinginan yang bersangkutan.Menurut (Bob Sabran 2012) Indikator produk yang digunakan dalam penelitian ini, yaitu:

a. Produk memiliki rasa yang sedap

b. Bumbu berbeda dengan produk lain

c. Disain kemasan yang menarik

d. Pisang sale renyah dan gurih

e. Produk yang ditawarkan sesuai dengan keinginan

\section{Harga}

Menurut Kotler dan Keller (2014), harga merupakan salah satu elemen buran pemasaran yang menghasilkan pendapatan, elemen lain menghasilkan budaya. Mungkin harga adalah elemen termudah dalam program pemasaran untuk disesuaikan fitur produk, saluran komunikasi membutuhkan lebih banyak waktu.

Menurut Handayani (2012) Penetapan harga merupakan suatu masalah yang sangat peka bagi perusahaan dalam penjualan produknya, karena pada dasarnya harga merupakan satu -satunya elemen dalam bauran pemasaran yang paling fleksibel dimana diubah dengan cepat.suatu tingkat harga dapat memberikan pengaruh baik dalam perekonomian maupun dalam perusahaan, hal ini disebabkan karna harga merupakan bagian penawaran suatu barang. 
Berdasarkan defenisi di atas, dapat disimpulkan yang dimaksud dengan harga adalah jumlah yang harus dibayarkan oleh konsumen yang dianggap layak untuk memperoleh atau memiliki produk dimana besarnya ditetapkan oleh perusahaan atau penjual. Menurut (Swasta 2010) Indikator harga yang digunakan dalam penelitian ini yaitu:

a. Harga yang terjangkau

b. Harga lebih rendah dari pesaing

c. Diskon d. Harga kompetitif

\section{Distribusi}

Distribusi adalah salah satu aspek dari pemasaran.Distribusi juga dapat diartikan sebagai kegiatan pemasaran yang berusaha memperlancar dan mempermudah penyampaian barang dan jasa dari produsen kepada konsumen, sehingga penggunaannya sesuai dengan yang diperlukan (jenis, jumlah, harga, tempat, dan saat dibutuhkan). Seorang atau sebuah perusahaan distributor adalah perantara yang menyalurkan produk dari pabrikan (manufacturer) ke pengecer (retailer). Setelah suatu produk dihasilkan oleh pabrik, produk tersebut dikirimkan (dan biasanya juga sekaligus dijual) ke suatu distributor. Distributor tersebut kemudian menjual produk tersebut ke pengecer atau pelanggan.

Menurut Tjiptono (2013), distribusi diartikan sebagai kegiatan pemasaran yang berusaha memperlancar dan mempermudah penyampaian barang dan jasa dari produsen kekonsumen, sehingga penggunaanya sesuai dengan yang diperlukan (jenis, jumlah, harga, tempat, dan saat dibutuhkan).

Defenisi diatas dapat disimpulkan bahwa distribusi atau tempat ialah dimana suatu aktivitas mempercepat, memperlancar usaha yang dilakukan dan merupakan lembagalembaga yang memasarkan produk . Faktor penting dalam pengembangan suatu usaha apabila letak lokasi yang strategis, mudah dijangkau, dan kemudahaan akses kendaraan dan penyaluran distributor.

Menurut Gregorius dan Adriana (2013). Indikator tditribusi yang digunakan dalam penelitian ini yaitu:

a. Memiliki tempat yang strategis

b. Mudah didapatkan (ditemukan)

c. Persedian pisang sale

\section{Promosi}

Promosi merupakan salah satu variabel marketing mix yang sangat penting yang dilakukan untuk membuka pangsa pasar yang baru atau memperluas jaringan pemasaran. Bagaimana berkualitasnya satu produk bila konsumen belum pernah mendengarkanya dan tidk yakin bahwa produk it akan berguna bagi mereka, maka merekan tidak akan pernah membelinya. Karena promosi merupakan aktivitas pemasaran yang berusaha menyebarkan informasi, mempengaruhi/membujuk atau mengingatkan pasar sasaran atas perusahaan dan produknya agar bersedia menerima, membeli dan loyal pada produk yang ditawarkan perusahaan yang bersangkutan.

Menurut Kotler dan Keller (2014) promosi penjualan merupakan bahan inti dalam kampanye pemasaran, terdiri dari koleksi alat intensif, sebagian besar jangka pendek, yang dirancang untuk menstimulsi pembelian yang lebih cepat atau lebih besar atas produk atau jasa tertentu oleh konsumen.

Menurut Swasta dan Irawan (2016), promosi adalah arus informasi atau persuasi satu arah yang dibuat untuk mengarahkan seseorang atau organisasi kepada tindakan yang 
menciptakan pertukaran dalam pemasaran. Suatu produk yang memiliki kualitas tinggi dan harga yang murah, namun tidak dikenal oleh pasar maka segala kelebihan antribut yang dimiliki produk tersebut menjadi siasia. Usaha untuk mengenalkan produk kepada pasar yaitu dilakukan strategi promosi dengan semua jenis kegiatan pemasaran yang ditunjukkan untuk mendorong permintaan.

Menurut Kotler dan Armstrong (2014) Promosi adalah aktivitas yang mengkomunikasikan keunggulan produk dan membujuk pelanggan untuk membeli produk itu.

Berdasarkan pendapat para ahli diatas dapat disimpulkan bahwa promosi adalah menginformasikan, mempengaruhi dan memebujuk serta mengingatkan pelanggan sasaran tentang perusahaan dan bauran pemasarannya. Meskipun secara umum bentuk-bentuk promosi memiliki fungsi yang sama, tetapi bentuk-bentuk tersebut dapat dibedakan berdasarkan tugas-tugas khususnya.

Menurut (Wibowo dan Karimah 2012) Indikator promosi yang digunakan dalam penelitian ini, yaitu:

a. Iklan melalui media cetak dan radio

b. Promosi melalui Media sosial

c. Pameran

d. Promosi mulut ke mulut

\section{Keputusan Pembelian}

Perilaku konsumen tidak hanya tentang apa yang dibeli atau dikonsumsi oleh konsumen saja, tetapi juga dimana,bagaimana kebiasaan dan dalam kondisi macam apa produk dan jasa yang dibeli.

Menurut Kotler dan Amstrong (2014) Perilaku konsumen merupakan perilaku pembelian konsumen akhir, baik individu maupun rumah tangga, yang membeli produk untuk konsumsi personal. Menurut Suharno (2010), keputusan pembelian adalah tahap dimana pembeli telah menentukan pilihannya dan melakukan pembelian produk, serta mengkonsumsinya. Pengambilan keputusan oleh konsumen untuk melakukan pembelian suatu produk diawali oleh adanya kesadaran atau kebutuhan dan keinginan.

Faktor-Faktor Yang Mempengaruhi Keputusan Pembelian Dalam mempelajari keputusan pembelian konsumen, seorang pemasar harus melihat hal-hal yang berhubungan trhadap keputusan pembelian dan membuat suatu ketentuan bagaimana konsumenn membuat keputusan pembeliannya.

Menurut Kotler dan Armstrong (2014) keputusan pembelian konsumen dipengaruhi oleh empat faktor,diantaranya sebagai berikut:

1) Faktor Budaya (Cultural) Budaya, sub budaya, dan kelas sosial sangat penting bagi perilaku pembelian.

Budaya merupakan penentu keinginan dan perilaku paling dasar. Anak-anak yang sedang tumbuh akan mendapatkan seperangkat nilai, persepsi, preferensi, dan perilaku dari keluarga dan lembaga-lembaga penting lainnya. Masing-masing subbudaya terdiri dari sejumlah subbudaya yang lebih menampakkan identifikasi dan sosialisasi khusus bagi para anggotanya seperti kebangsaan, agama, kelompok, ras, dan wilayah geografis.

2) Faktor Sosial (Social) Selain faktor budaya, perilaku pembelian konsumen juga dipengaruhi oleh faktor sosial diantarannya sebagai berikut :

a. Kelompok referensi 
Kelompok acuan dalam perilaku pembelian konsumen dapat diartikan sebagai kelompok yang yang dapat memberikan pengaruh secara langsung atau tidak langsung terhadap sikap atau perilaku seseorang tersebut. Kelompok ini biasanya disebut dengan kelompok keanggotaan, yaitu sebuah kelompok yang dapat memberikan pengaruh secara langsung terhadap seseorang.

b. Keluarga

Keluarga dibedakan menjadi dua bagian dalam sebuah organisasi pembelian konsumen. Pertama keluarga yang dikenal dengan istilah keluargaorientasi. Keluarga jenis ini terdiri dari orang tua dan saudara kandung seseorang yang dapat memberikan orientasi agam, politik dan ekonomi serta ambisi pribadi, harga diri dan cinta. Kedua, keluarga yang terdiri dari pasangan dan jumlah anak yang dimiliki seseorang. Keluarga jenis ini biasa dikenal dengan keluarga prokreasi.

c. Peran dan status

Hal selanjutnya yang dapat menjadi faktor sosial yang dapat mempengaruhi perilaku pembelian seseorang adalah peran dan status mereka di dalam masyarakat. Semakin tinggi peran seseorang didalam sebuah organisasi maka akan semakin tinggi pula status mereka dalam organisasi tersebut dan secara langsung dapat berdampak pada perilaku pembeliannya. Contoh seorang direktur di sebuah perusahaan tentunya memiliki status yang lebih tinggi dibandingkan dengan seorang supervisor,begitu pula dalam perilaku pembeliannya. Tentunya, seorang direktur perusahaan akan melakukan pembelian terhadap merek-merek yang berharga lebih mahal dibandingkan dengan merek lainnya.

3) Faktor Pribadi (Personal) Keputusan pembelian juga dapat dipengaruhi oleh karakterisitik pribadi diantaranya usia dan tahap siklus hidup, pekerjaan,keadaan ekonomi, gaya hidup, serta kepribadian dan konsep-diri pembeli.

a. Usia dan siklus hidup keluarga

Orang membeli barang dan jasa yang berbeda-beda sepanjang hidupnya yang dimana setiap kegiatan konsumsi ini dipengaruhi oleh siklus hidup keluarga

b. Pekerjaan dan lingkungan ekonomi

Pekerjaan dan lingkungan ekonomi seseorang dapat mempengaruhi pola konsumsinya. Cotohnya, direktur perusahaan akan membeli pakaian yang mahal, perjalanan dengan pesawat udara, keanggotaan di klub khusus, dan membeli mobil mewah. Selain itu, biasanya pemilihan produk juga dilakukanberdasarkan oleh keadaan ekonomi seseorang seperti besaran penghasilan yang dimiliki, jumlah tabungan, utang dan sikap terhadap belanja atau menabung.

c. Gaya hidup

Gaya hidup dapat di artikan sebagai sebuah pola hidup seseorang yangterungkap dalam aktivitas, minat dan opininya yang terbentuk melalui sebuah kelas sosial, dan pekerjaan. Tetapi, kelas sosial dan pekerjaan yang samatidak menjamin munculnya sebuah gaya hidup yang sama. Melihat hal ini sebagai sebuah peluang dalam kegiatan pemasaran, banyak pemasar yang mengarahkan merek merea kepada gaya hidup seseorang.

d. Kepribadian 
Setiap orang memiliki berbagai macam karateristik kepribadian yang bebedabeda yang dapat mempengaruhi aktivitas kegiatan pembeliannya. Kepribadian merupakan ciri bawaan psikologis manusia yang berbeda yang menghasilkan sebuah tanggapan relatif konsiten dan bertahan lama terhadap rangsangan lingkungannya. Kepribadian dapat menjadi variabel yang sangat berguna dalam menganalisis pilihan merek konsumen. Hal ini disebakan karena beberapa kalangan konsumen akan memilih merek yang cocok dengan kepribadiannya.

4) Faktor Psikologis(Psychological) Terakhir, faktor yang dapat mempengaruhikeputusan pembelian konsumen adalah faktor psikologis. Faktor ini dipengaruhi oleh empat faktor utama diantaranya sebagai berikut:

a. Motivasi

Seseorang memiliki banyak kebutuhan pada waktu waktu tertentu. Beberapa dari kebutuhan tersebut ada yang muncul dari tekanan biologis seperti lapar, haus, dan rasa ketidaknyamanan. Sedangkan beberapa kebutuhan yang lainnya dapat bersifatpsikogenesis; yaitu kebutuhan yang berasal dari tekanan psikologis seperti kebutuhan akan pengakuan, penghargaan atau rasa keanggotaan kelompok. Ketika seseorang mengamati sebuah merek, ia akan bereaksi tidak hanya pada kemampuan nyata yang terlihat pada merek tersebut, melainkan juga melihat petunjuk lain yang samar.

b. Persepsi

Seseorang yang termotivasi siap untuk segera melakukan tindakan. Bagaimana tindakan seseorang yang termotivasi akan dipengaruhi oleh persepsinya terhadap situasi tertentu. Persepsi dapat diartikan sebagai sebuah proses yang digunkan individu untuk memilih, mengorganisasi, dan menginterpretasi masukan informasi guna menciptakan sebuah gambaran. Persepsi tidak hanya bergantung pada rangsangan fisik tetapi juga pada rangsangan yang berhubungan dengan lingkungan sekitar dan keadaan individu yang bersangkutan.

c. Pembelajaran

Pembelajaran meliputi perubahan perilaku seseorang yang timbul dari pengalaman. Banyak ahli pemasaran yang yakin bahwa pembelajaran dihasilkan melalui perpaduan kerja antara pendorong, rangsangan, isyarat bertindak, tanggapan dan penguatan. Teori pembelajaran mengajarkan kepada para pemasar bahwa mereka dapat membangung permintaan atas suatu produk dengan mengaitkan pada pendorongnya yang kuat, menggunakan isyarat yang memberikan motivasi, dan memberikan penguatan positif karena pada dasarnya konsumen akan melakukan generalisasi terhadap suatu merek.

d. Keyakinan dan Sikap

Melalui betindak dan belajar, orang mendapatkan keyakinan dan sikap. Keduanya kemudian mempengaruhi perilaku pembelian konsumen . Keyakinan dapat diartikan sebgai gambaran pemikiran seseorang tentang gambaran sesuatu. Keyakinan orang tentang produk atau merek akan mempengaruhi keputusan pembelian mereka. Selain keyakinan, sikap merupakan hal yang tidak kalah pentingnya. Sikap adalah evaluasi, perasaan emosi, dan kecenderungan tindakan yang menguntungkan atau tidak 
menguntungkan dan bertahan lama pada seseorang terhadap suatu objek atau gagasan tertentu.

\section{Proses Keputusan Pembelian}

Menurut (Kotler dan Keller 2013) proses keputusan pembelian sebagai berikut:

1) Pengenalan Masalah (Problem Recognition)

Proses pembeli dimulai dengan pengenalan masalah atau kebutuhan. Pembeli menyadari suatu perbedaan antara keadaan sebenarnya dan keadaan yang diinginkannya. Kebutuhan itu dapat digerakkan oleh rangsangan dari dalam diri pembeli atau dari luar. Pemasar perlu mengenal berbagai hal yang dapat menggerakkan kebutuhan atau minat tertentu dalam konsumen.

2) Pencarian Informasi (Information Search)

Seorang konsumen yang mulai tergugah minatnya mungkin akan atau mungkin tidak mencari informasi yang lebih banyak lagi. Jika dorongan konsumen adalah kuat, dan obyek yang dapat memuaskan kebutuhan itu tersedia, konsumen akan membeli obyek itu. Jika tidak, kebutuhan konsumen itu tinggal mengendap dalam ingatannya dan tidak lebih lanjut mencari informasi sehubungan dengan kebutuhan itu.

3) Penilaian Alternatif (Evaluation of Alternatives)

Setelah melakukan pencarian informasi sebanyak mungkin tentang banyak hal, selanjutnya konsumen harus melakukan penilaian tentang beberapa alternatif yang ada dan menentukan langkah selanjutnya.

4) Keputusan Membeli (Purchase Decision)

Setelah tahap-tahap awal tadi dilakukan, sekarang tiba saatnya bagi pembeli untuk menentukan pengambilan keputusan apakah jadi membeli atau tidak. Jika keputusan menyangkut jenis produk, bentuk produk, merek, penjual, kualitas dan sebagainya.

5) Perilaku setelah pembelian (Postpurchase Behavior)

Setelah membeli suatu produk, konsumen akan mengalami beberapa tingkat kepuasan atau tidak ada kepuasan. Ada kemungkinan bahwa pembeli memiliki ketidakpuasan setelah melakukan pembelian, karena mungkin harga barang dianggap terlalu mahal, atau mungkin karena tidak sesuai dengan keinginan atau gambaran sebelumnya dan sebagainya. Untuk mencapai keharmonisan dan meminimumkan ketidakpuasan pembeli harus mengurangi keinginan-keinginan lain sesudah pembelian, atau juga pembeli harus mengeluarkan waktu lebih banyak lagi untuk melakukan evaluasi sebelum membeli.

\section{Indikator Keputusan Pembelian}

Menurut Kotler dan Amstrong (2014) proses pengambilan keputusan pembelian yang akan dilakukan oleh konsumen merupakan indikator keputusan pembelian yang digunakan dalam penelitian ini. (1) Pengenalan masalah (2) Pencarian Informasi (3) Evaluasi Alternatif (4) Keputusan Pembelian (5) Perilaku setelah pembelian.

\section{Hipotesis}

Hipotesis adalah suatu pernyataan sementara atau dugaan yang paling memungkinkan yang masih harus dicari kebenarannya. Hubungan dalam penelitian ini memiliki hipotesis sebagai berikut:

1) Terdapat pengaruh yang positif dan signifikan produk secara parsial terhadap Keputusan Pembelian UMKM Sale Pisang Purwobakti Muaro Bungo. 
2) Terdapat pengaruh yang negatif dan signifikan Harga secara parsial terhadap Keputusan Pembelian UMKM Sale Pisang Purwobakti Muaro Bungo.

3) Terdapat pengaruh yang negatif dan signifikan Distribusi secara parsial terhadap Keputusan Pembelian UMKM Sale Pisang Purwobakti Muaro Bungo.

4) Terdapat pengaruh yang positif dan signifikan Promotion secara parsial terhadap Keputusan Pembelian UMKM Sale Pisang Purwobakti Muaro Bungo.

5) Terdapat pengaruh positif dan signifikan Produk, Harga, Distribusi, dan Promotion secara bersama-sama terhadap Keputusan Pembelian UMKM Sale Pisang Purwobakti Muaro Bungo.

\section{METODE PENELITIAN}

\section{Populasi}

MenuruSugiyono (2015), Populasi adalah wilayah generalisasi yang terdiri atas: objek/subjek yang mempunyai kualitas dan karakteristik tertentu yang ditetapkan oleh peneliti untuk dipelajari dan kemudian ditarik kesimpulannya.

Jadi populasi bukan hanya orang, tetapi jiga objek dan benda-benda alam yang lain. Populasi bukan hanya sekedar jumlah yang ada pada objek/subjek yang dipelajari, tetapi meliputi seluruh karakteristik / sifat yang dimiliki oleh subjek/objek itu.Dalam penelitian ini yang menjadi populasi adalah konsumen pada UMKM sale pisang purwobakti muaro bungo dan jumlah populasi yang diambil tahun 2017 adalah 175.000 orang.

\section{Sampel}

MenurutSugiyono (2015) Sampel adalah bagian dari jumlah dan karakteristik yang dimiliki oleh populasi tersebut. Bila populasi besar, dan peneliti tidak mungkin mempelajari semua yang ada pada populasi, misalnya karena keterbatasan dana, tenaga dan waktu, maka peneliti dapat menggunakan sampel yang diambil dari populasi itu. Apa yang dipelajari dari sampel itu, kesimpulannya akan dapat diberlakukan untuk populasi. Untuk itu sampel yang diambil dari populasi harus betul-betul representative (mewakili).Maka perhitungan jumlah sampel didasarkan pada rumus formula statisticSlovin sebagai berikut:

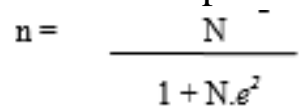

Dimana:

$\mathrm{n}=$ ukuran sampel

$\mathrm{N}=$ ukuran populasi

$\mathrm{e}=$ kesalahan sampel (error)

maka jumlah sampel minimum yang diambil adalah

$$
\begin{aligned}
& \mathrm{n}=\frac{\mathrm{N}}{1+\mathrm{N} \cdot \mathrm{e}^{2}} \\
& \mathrm{n}=\frac{175 \cdot 000}{1+175 \cdot 000 \cdot(0,1)^{2}}
\end{aligned}
$$

$\mathrm{n}=99,9$

$\mathrm{n}=100$ responden

Jadi pengolahan data sampel diatas dapat ditentukan bahwa jumlah sampel dalam penelitian ini sebanyak 100 responden. Pengambilan sampel dalam penelitian ini dilakukan 
dengan menggunakan teknik accidental sampling. Menurut Sugiyono (2016:124), accidentalsampling adalah teknik penentuan sampel berdasarkan kebetulan, yaitu siapa saja yang secara kebetulan/insidental bertemu dengan peneliti dapat digunakan sebagai sampel.

\section{Analisis Regresi Linier Berganda}

Penelitian ini menggunakan model analisis regresi linear untuk pembuktianhipotesis penelitian. Analisis ini akan menggunakan input berdasarkan data yangdiperoleh dari kuesioner. Perhitungan statistik dalam analisis regresi linearberganda yang digunakan dalam penelitian ini adalah dengan menggunakanbantuan program SPSS (Statistical Package for Social Science). Menurut Sugiyono(2014:267) secara umum regresi berganda dapat dirumuskan sebagai berikut :

Rumus :

$\mathrm{Ya}+\mathrm{b}_{1} \mathrm{X}_{1}+\mathrm{b}_{2} \mathrm{X}_{2}+\mathrm{b}_{3} \mathrm{X}_{3+} \mathrm{b}_{1} \mathrm{X}_{1+}$

Keterangan :

$\mathrm{Y}=$ Keputusan Pembelian

$\mathrm{X} 1$ = Produk

$\mathrm{X} 2=$ Harga

$\mathrm{X} 3=$ Tempat

$\mathrm{X} 4 \quad=$ Promosi

$\mathrm{a}=$ Konstanta

b1, b2 = koefisen regresi masing-masing variabel

$\mathrm{e}=$ Standar eror (kesalahan pengganggu)

\section{Pengujian secara parsial (Uji t)}

Uji t yaitu suatu uji untuk mengetahui signifikasi pengaruh variabel bebas yaitu Produk (X1)Harga (X2), Tempat (X3), dan Promosi (X4) secara parsial atau individual terhadap variabel terikat yaitu Keputusan Pembelian (Y). Untuk mengujinya menurut (Sugiyono, 2014: 250) yaitu dengan rumus sebagai berikut :

Rumus : thitung =

$r \cdot \frac{\sqrt{n-k-1}}{1-r^{2}}$

Keterangan :

$\mathrm{r}=$ Koefisien korelasi parsial

$\mathrm{k}=$ jumlah variabel independent

$\mathrm{n}=$ jumlah data kriteria yang digunakan adalah :

1) H0 : b1 = 0, artinya variabel (X1), Harga (X2) Tempat (X3) dan Promosi (X4)tidak berpengaruh secara parsial terhadap keputusan pembelian (Y).

2) H0 : b1> 0, artinya variabel (X1), Harga (X2) Tempat (X3) dan Promosi (X4) berpengaruh positif secara parsial terhadap Keputusan Pembelian (Y). Sedangkan kriteria pengujiannya adalah sebagai berikut :

a. Taraf signifikan $(a=0,05)$

b. Distribusi t dengan derajat kebebasan (dk/df)

c. Apabila thitung > t tabel, maka $\mathrm{H} 0$ ditolak, dan Ha diterima

d. Apabila thitung $\leq \mathrm{t}$ tabel, maka H0 diterima, dan Ha ditolak.

Rumus : to $=$ 


$$
\frac{b i}{s b i}
$$

Dimana:

to $=$ Nilai pengujian

bi=Koefisien regresi sbi=Standar error atas koefisien regresi

\section{Pengujian secara simultan (Uji F)}

Uji F yaitu suatu uji untuk mengetahui pengaruh variabel bebas, yaitu Produk (X1), Harga (X2) Tempat (X3) dan Promosi (X4), secara simultan terhadap variabel terikat yaitu Keputusan Pembelian (Y).Untuk mengetahui apakah variabel bebas secara simultan berpengaruh signifikan terhadap variabel terikat digunakan rumus Prayitno (2010:31) :

Rumus : Fhitung=

$$
: F_{\text {litiumg }}=\frac{R^{2} / k}{\left(1-R^{2}\right) /(N-k-1)}
$$

Keterangan :

$\mathrm{F}=$ Fhitungselanjutnya dibandingkan dengan $\mathrm{F}$ tabel

R2= Koefisien Determinasi

$\mathrm{K}=$ Jumlah variabel

$\mathrm{N}=$ Banyaknya sampel

Perumusan hipotesisnya adalah sebagai berikut:

a. $\quad \mathrm{H} 0: \mathrm{b} 1=\mathrm{b} 2=\mathrm{b} 3=0$ Artinya secara bersama-sama tidak ada pengaruh yang signifikan dari variabel bebas, yaitu, Produk (X1), Harga (X2) Tempat (X3) dan Promosi (X4)secara simultan terhadap variabel terikat yaitu Keputusan Pembelian(Y).

b. Ha : $\mathrm{b} 1 \neq \mathrm{b} 2 \neq \mathrm{b} 3 \neq 0$ Artinya secara bersama-sama ada pengaruh yang signifikan dari variabel bebas, yaitu Produk (X1), Harga (X2) Tempat (X3) dan Promosi (X4)terhadap variabel terikat yaitu Loyalitas Nasabah (Y).

c. Pengujian dengan uji $\mathrm{F}$ variansnya adalah dengan membandingkan Fhitung (Fh) dengan Ftabel (Ft) pada $\square=0,05$ apabila hasil perhitungannya menunjukkan: 1 . Fh $\geq \mathrm{Ft}$, maka $\mathrm{H} 0$ ditolak dan Ha diterima 2. Fh< Ft, maka H0 diterima dan Ha ditolak.

\section{Koefisien determinasi (R2)}

Koefisien determinasi (R2) digunakan untuk menjelaskan proporsi variabel terikat yang mampu dijelaskan oleh variabel- variabel bebasnya.Nilai koefisien determinasi adalah $0<$ R2<1. Nilai R2 yang kecil berarti kemampuan variabel bebas yaitu Produk (X1), Harga (X2) Tempat (X3) dan Promosi (X4)dalam menjalankan variabel terikat yaitu Keputusan Pembelian (Y) sangat terbatas. Nilai yang mendekati satu berarti variabel bebas yaitu Produk (X1), Harga (X2), Distribusi (X3), dan Promosi (X3), dapat memberikan hampir semua informasi yang dibutuhkan untuk memprediksi semua variabel terikat yaitu Keputusan Pembelian (Y).

Menurut Algifari (2011:64) mencari koefisien Determinasi (R2) digunakan : Rumus :

$$
R^{2}=\frac{\sum\left(\gamma-\gamma^{n}\right)^{2}}{\sum\left(\gamma-\gamma^{N}\right)^{2}}
$$

Dari koefisien determinasi (R2) dapat diketahui ketepatan dari analisis regresi linear berganda.R2 merupakan besarnya variabel sumbangan seluruh variabel terikat. Interprestasi terhadap hasil koefisien determinasi (R2) berarti: 
1) Jika nilai koefisien determinasi (R2) semakin mendekti 1 Jadi semakin besar R2 semakin tepat regresi yang dipakai sebagai alat peramalan karena total variasi dapat menjelaskan variabel loyalitas Nasabah.

2) Jika nilai koefisien determinasi (R2) semakin mendekati 0 maka sumbangan variabael diatas terhadap variabel bebas dan vaiabel terikat semakin kecil. Secara umum dapat dikatakan bahwa besarnya koefisien determinasi pada (R2) berada antara 0 dan 1 atau $0<$ R2> 1 .

\section{Perbandingan Hasil Penelitian}

a. Pengaruh Produk terhadap Keputusan pembelian

Berdasarkan penelitian yang dilakukan secara parsial produk berpengaruh positif dan signifikan terhadap keputusan pembelian pada UMKM Sale Pisang Purwobakti Muaro Bungo. Dapat diartikan bahwa semakin bagus produk atau kualitas produk yang ditawarkan UMKM Sale Pisang maka hal tersebut akan mempengaruhi keputusan pembelian. Menurut Tjiptono (2013) produk adalah segala sesuatu yang ditawarkan produsen untuk diperhatikan, diminta, dicari, dibeli, digunakan, atau dikonsumsi pasar sebagai pemenuhan kebutuhan atau keinginan pasar yang bersangkutan.

Hasil penelitian ini sesuai dengan penelitian yang dilakukan Lembang (2013), dengan judul "Pengaruh kualitas produk, harga, promosi, dan cuaca terhadap keputusan pembelian teh siap minum dalam kemasan merek Teh Botol Sosro di Semarang“. Terbukti bahwa kualitas produk berpengaruh positif dan signifikan terhadap keputusan pembelian teh siap minum dalam kemasan merek Teh Botol Sosro di Semarang.

Berdasarkan hasil itu untuk meningkatkan keputusan pembelian pada produk Sale Pisang, maka dapat di rekomendasikan melalui indikator variabel produk:

1) Produk memiliki rasa yang sedap

2) Bumbu berbeda dengan produk lain

3) Disain kemasan yang menarik

4) Pisang sale renyah dan gurih

5) Produk yang ditawarkan sesuai dengan keinginan

b. Pengaruh harga terhadap keputusan pembelian

Berdasarkan penelitian yang dilakukan secara parsial harga berpengaruh negatif dan tidak signifikan terhadap keputusan pembelian pada UMKM Sale Pisang Purwobakti Muaro Bungo. Dapat diartikan bahwa semakin terjangkau harga yang ditawarkan UMKM Sale Pisang maka hal tersebut akan mempengaruhi keputusan pembelian. Menurut Dinawan (2013), harga merupakan jumlah uang yang harus dibayar oleh pelanggan untuk memperoleh suatu produk.

Harga merupakan satu-satunya unsur bauran pemasaran yang memberikan pemasukan atau pendapatan bagi perusahaan, sedangkan ketiga unsur lainnya (Produk, Promosi dan Distribusi) menyebabkan timbulnya biaya. Hasil penelitian ini sesuai dengan penelitian yang dilakukan Tan (2011), dengan judul "pengaruh faktor harga, promosi dan pelayanan terhadap keputusan pembelian untuk belanja di Alfamart Surabaya". Dengan demikian terbukti bahwa harga berpengaruh negatif dan tidak signifikan terhadap keputusan pembelian untuk belanja di Alfamart Surabaya.

Berdasarkan hasil itu untuk meningkatkan keputusan pembelian pada produk Sale Pisang, maka dapat di rekomendasikan melalui indikator variabel harga:

1) Harga yang terjangkau

2) Harga lebih rendah dari pesaing 
3) Diskon

4) Harga kompetitif

c. Pengaruh Distribusi terhadap Keputusan pembelian

Berdasarkan penelitian yang dilakukan secara parsial distribusi berpengaruh negatif dan tidak signifikan terhadap keputusan pembelian pada UMKM Sale Pisang Purwobakti Muaro Bungo. Dapat diartikan bahwa semakin luas distribusi yang ditawarkan UMKM Sale Pisang maka hal tersebut akan mempengaruhi keputusan pembelian.

Menurut Tjiptono (2013) Lokasi atau tempat seringkali ikut menentukan kesuksesan perusahaan, karena lokasi erat kaitanya dengan pasar potensial sebuah perusahaan. Hasil penelitian ini sesuai dengan penelitian yang dilakukan Soraya (2011), berjudul "Pengaruh Bauran Pemasaran Jasa terhadap Keputusan Pembelian Konsumen pada Gardenia Cafe Medan. Distribusi berpengaruh positif dan signifikan terhadap Keputusan Pembelian Konsumen pada Gardenia Cafe Medan.

Berdasarkan hasil itu untuk meningkatkan keputusan pembelian pada produk Sale Pisang, maka dapat di rekomendasikan melalui indikator variabel distribusi:

1) Memiliki tempat yang strategis

2) Mudah didapatkan

3) Persedian pisang sale

d. Pengaruh Promosi terhadap Keputusan pembelian

Berdasarkan penelitian yang dilakukan secara parsial promosi berpengaruh positif dan signifikan terhadap keputusan pembelian pada UMKM Sale Pisang Purwobakti Muaro Bungo. Dapat diartikan bahwa semakin tinggi promosi yang dilakukan UMKM Sale Pisang maka hal tersebut akan mempengaruhi keputusan pembelian.

Menurut Kotler dan Keller (2014) promosi penjualan merupakan bahan inti dalam kampanye pemasaran, terdiri dari koleksi alat intensif, sebagian besar jangka pendek, yang dirancang untuk menstimulsi pembelian yang lebih cepat atau lebih besar atas produk atau jasa tertentu oleh konsumen. Hasil penelitian ini sesuai dengan penelitian yang dilakukan Tri Yulianti (2013), dengan judul "Pengaruh Promotional Mix Terhadap Keputusan Pembelian Sepeda Motor Yamaha Pada Masyarakat Kecamatan Jebres Surakarta".Dengan demikian terbukti bahwa promosi berpengaruh positif dan signifikan terhadap keputusan pembelian sepeda motor yamaha.

Berdasarkan hasil itu untuk meningkatkan keputusan pembelian pada produk Sale Pisang, maka dapat di rekomendasikan melalui indikator variabel promosi:

1) Iklan melalui media cetak dan radio

2) Promosi melalui Media social

3) Pameran

4) Promosi mulut ke mulut

e. Pengaruh Produk, Harga, Distribusi dan Promosi terhadap Keputusan Pembelian

Berdasarkan penelitian yang dilakukan secara bersama-sama produk, harga, distribusi dan promosi berpengaruh positif dan signifikan terhadap keputusan pembelian pada UMKM Sale Pisang Purwobakti Muaro Bungo. Dapat diartikan bahwa semakin baik produk, harga, distribusi dan promosi yang dilakukan UMKM Sale Pisang maka hal tersebut akan mempengaruhi Keputusan pembelian. Hasil penelitian ini sesuai dengan penelitian yang dilakukan Soraya (2011).

Pengaruh Bauran Pemasaran Jasa terhadap Keputusan Pembelian Konsumen pada Gardenia Cafe Medan. Menunjukan bahwa variabel Produk, Harga, distribusi, Promosi, dan Proses mempunyai pengaruh positif dan signifikan terhadap keputusan pembelian. 
Berdasarkan hasil itu untuk meningkatkan minat pembelian pada produk Sale Pisang, maka dapat di rekomendasikan melalui indikator variabel keputusan pembelian:

1) Pengenalan masalah.

2) Pencarian informasi.

3) Evaluasi alternative.

4) Keputusan pembelian.

5) Perilaku pasca pembelian.

\section{KESIMPULAN DAN SARAN}

\section{Kesimpulan}

Adapun kesimpulan yang dapat diberikan sehubungan dengan hasil penelitian ini dapat diurutkan sebagai berikutini :

1) Terdapat pengaruh positif dan signifikan antara produk dengan keputusan pembelian. Dimana diperoleh t-hitung lebih besar dari t-tabel $(15,651>1,985)$ dengan tingkat signifikan lebih kecil dari alpha $(0,000<0,05)$.

2) Terdapat pengaruh negatif dan tidak signifikan antara harga dengan keputusan pembelian. Dimana diperoleh t-hitung lebih kecil dari t-tabel $(-0,490<1,985)$ dengan tingkat signifikan lebih besar dari alpha $(0,625>0,05)$.

3) Terdapat pengaruh negatif dan tidak signifikan antara distribusi dengan keputusan pembelian. Dimana diperoleh t-hitung lebih kecil dari t-tabel $(-0,102<1,985)$ dengan tingkat signifikan lebih besar dari alpha $(0,919>0,05)$.

4) Terdapat pengaruh positif dan signifikan antara promosi dengan keputusan pembelian. Dimana diperoleh t-hitung lebih besar dari t-tabel $(3,231>1,985)$ dengan tingkat signifikan lebih kecil dari alpha $(0,002<0,05)$.

5) Terdapat secara bersama-sama pengaruh positif dan signifikan antara produk, harga, distribusi, dan promosi terhadap keputusan pembelian, dibutkikan dengan F-hitung lebih besar dari F-tabel $(80,644>2,47)$ atau tingkat signifikan lebih kecil dari alpha $(0,000<0,05)$.

\section{Keterbatasan Masalah}

Penelitian ini telah diusahakan dan dilaksanakan sesuai dengan prosedur ilmiah, namun demikian masih memiliki keterbatasan yaitu :

1) Keterbatasan variabel Produk, Harga, Distribusi dan Promosi hanya mampu menyumbang $79,8 \%$ terhadap Minat Pembelian.

2) Penelitian ini memiliki variabel terikatnya Keputusan Pembelian.

\section{Saran}

Berdasarkan kesimpulan yang telah dibuat, maka penulis mengemukakan beberapa saran sebagai berikut:

Bagi Pihak Umkm Sale Pisang:

1) Keputusan pembelian akan meningkat apabila pihak management mampu meningkatkan Produk melalui indikator produk memiliki rasa yang sedap, bumbu berbeda dengan produk lain, desain kemasan yang menarik, pisang sale renyah dan gurih, produk yang ditawarkan sesuai dengan keinginan.

2) Keputusan pembelian akan meningkat apabila pihak management mampu meningkatkan Promosi melalui indikator iklan melalui media cetak dan radio, promosi melalui media sosial, pameran, promosi mulut ke mulut. 
3) Keputusan pembelian akan meningkat apabila pihak management mampu meningkatkan Distribusi melalui indikator memiliki tempat yang strategis, mudah didapatkan, persedian pisang sale umkm.

4) Keputusan pembelian akan meningkat apabila pihak management mampu menurunkan Harga melalui indikator harga yang terjangkau, harga lebih rendah dari pesaing, diskon, harga kompetitif.

Bagi Penelitian Selanjutnya

1) Menambah Variabel lain yang tidak diteliti

2) Menggunakan Produk, Harga, Distribusi, dan Promosi sebagai variabel intervening lain yang tidak diteliti..

\section{DAFTAR RUJUKAN}

Buku :

Algifari. 2011. Kausal Komperatif, Teori, Kasus Dan Solusi. BPFE UGM, Yogyakarta.

Assauri, Sofjan. 2014. Manajemen Pemasaran. Jakarta: Pt Raja Grafindo Persada.

Ghozali, Imam. 2011. Aplikasi Analisismultivariate Dengan Program Spps. Semarang: Badan Penebit Universitas Diponegoro.

Kotler dan Keller. 2013. Manajemen Pemasara. Edisi Ketiga Belas, Jilid 2. Jakarta: Erlangga. Lovelock, Chritopher.Et Al. 2010. Pemasaran Jasa. Jakarta: Erlangga.

Lupiyadi, Rambat Dan Hamdani A. 2013. Manajemen Pemasaran Jasa. Jakarta: Salemba Empat.

Riduwan. 2015. Metode \& Teknik Menyusun Proposal Penelitian Bandung: Alfabeta.

Setiyaningrum, Ari, Jusuf Udaya Dan Efendi. 2015. Prinsip-Prinsip Pemasaran. Yogyakarta: Perpustakaan Nasional.

Siregar, Syofian. 2015. Statistik Parametrik Untuk Penelitian Kuantatif. Jakarta: Bumi Aksara.

Sugiyono. 2013. Metode Penelitan Kuantitatif Kualitatif Dan R\&D. Bandung: Penerbit: Alfabeta.

Sugiyono. 2014. Metode Penelitan Kuantitatif Kualitatif Dan R\&D. Bandung: Penerbit: Alfabeta.

Sugiyono. 2016. Metode Penelitan Kuantitatif Kualitatif Dan R\&D. Bandung: Penerbit: Alfabeta.

Tjiptono, Fandy, Gregorius Chandra. 2012. Pemasaran Strategik Edisi 2. Yogyakarta. Cv Ando Offset

Umar, Husein. 2014. Metode Penelitian Untuk Skripsi Dann Tesis Bisnis, Edisi Kedua. Jakarta: Pt Rajagrafindo Persada.

Jurnal dan Skripsi :

Herawati, Arvinia, Ari Pradhanawati dan Reni Shinta Dewi. 2013. Pengaruh Bauran Pemasaran Ritel Terhadap Loyalitas Pelanggan Melalui Kepuasan Pelanggan Pada Konsumen Alfamart Di Kecamatan Tembalang Semarang. Journal Of Social And Politic.

Hermawan, Haris. 2015. Analisis Pengaruh Bauran Pemasaran Terhadap Keputusan, Konsumen Dalam Pembelian Roti Ceria Di Jember. Jurnal Manajemen Dan Binis Indonesia Vol. 1, No.2 
Kementerian UMKM. Statistik Usaha Mikro, Kecil dan Menengah Tahun 2010-2011. diakses dari www.depkop.go.id pada tanggal 24 Juni 2015.

Irawati, Ciendra dan Hartono Subagio. 2014. Pengaruh Retail Mix Terhadap Loyalitas Konsumen Dengan Customer Satisfaction Sebagai Variabel Intervening Di Giordano

Ciputra World Surabaya. Jurnal Manajemen Pemasaran Petra Vo.2, No. 1

Larasati. 2015. Pengaruh Marketing Mix Terhadap Keputusan Pembelian Mobil, Daihatsu Di Kota Padang (Studi Kasus Pada Konsumen Mobil Daihatsu D Kota Padang). Skripsi Universitas Putra Indonesia "Yptk" Padang.

Mardatillah, Ilham. 2016. Pengaruh Kualitas Pelayanan, Harga Dan Lokasi Pada Kepuasan Pelanggan Pada Hotel Pengeran Beach Padang. Skripsi Universitas Putra Indonesia "Yptk" Padang.

Melisa, Yuda. 2012. Pengaruh Bauran Pemasaran Ritel Terhadap Keputusan Pembelian Ulang Konsumen Mega Prima Swalayan Payakumbuh. Jurnal Manajemen Vol.01, No.01

Miftah, Fuad. 2016. Pengaruh Lokasi, Harga Dan Promosi Terhadap Keputusan Pembelian Pada Minimarket Afdal Mart Di Filano Parak Karakah Padang. Skripsi Universitas Putra Indonesia "Yptk" Padang.

Suprihati, Wikan Budi Utami. 2015. Analisis Fakor-Faktor Yang Mempengaruhi Perilaku Konsumen Dalam Keputusan Pembelian Mobil Pribadi Di Kelurahan Gonilan Kabupaten Sukoharjo. STIE AAS Surakarta. 